
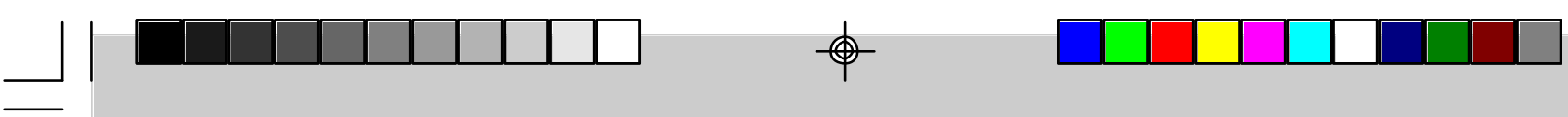

Sylvia Walby

\title{
Contributions
}

\section{to an agenda for \\ Sociology for \\ the 21st century}

The paper sets out three aspects of an agenda for Sociology in the 21st Century. First, sociology needs to develop its central concerns beyond those of Marx, Weber and Durkheim and engage with the questions posed by gender and ethnic as well as class relations. Secondly, sociology needs to move beyond selflimitation to the nation-state, and engage with the analysis of the developing European Union and also globalisation. Thirdly, sociology should be proud of its place in the Enlightenment tradition, further develop its scientific methods, and not retreat into relativism. 


\section{Introduction}

The creation of a new programme of sociology is an occasion to be marked with much celebration. Sociology can make important contributions to society and to the development of knowledge. I shall address some, though obviously not all, of the debates as to the future development of sociology.

Firstly, sociology needs to move decisively beyond the problematic of class and industrial society which is the focus of our traditional canon of Marx, Weber and Durkheim. This classical tradition neglects the analysis of other deeply institutionalised social divisions and inequalities, especially those of gender and of ethnicity. This trilogy of classical writers has never been adequate for sociological enquiry; this insufficiency is not merely new. For instance, feminist sociology at the turn of the century was represented by analysts such as Charlotte Perkins Gilman. In order to develop within the academy Women's Studies has forged a separate intellectual space, such was the insufficiency of traditional sociology. One of our questions now is what should be the relationship between sociology and Women's Studies in a newly forming sociology programme. How are the questions raised by a gender analysis to be re-integrated into sociology?

Secondly, sociology should address the challenge of the increasing integration of the European Union (EU) and play its part in the social analysis which underpins the creation of new European institutions. Whatever one's view of the EU, it exists and is developing, indeed whichever way Denmark votes in the referendum on the Treaty of Amsterdam. The failure of the voices and analysis of sociology to be heard adequately within the debates on the EU indicates a structural weakness in the institutional form of sociology. More analyses and institutional connections need to be made. The EU itself cannot be understood outside of the wider context of the debates on globalisation. The significance of this European question has been one of the reasons behind the creation of the European Sociological Association. This association was formed just after the wall came down between East and West in Europe, and these various transformations are at the heart of its intellectual project.

Thirdly, sociology should embrace the definition of itself as scientific in its methodology, and not let modesty and humility about the frailty and imperfections of social science knowledge, nor the sometimes politically horrendous uses to which it has been put, detract from this. We are in danger of allowing relativism and culturalism diminish the potential contribution of sociology to knowledge and to society. The improvement of knowledge by systematic enquiry and data collection about the social, not merely the textual, world, as well as theoretical development is a necessary feature of this. We could be bolder about our knowledge claims and develop the methodologies that we use to support them.

\section{Revising the canon: Including gender and ethnicity}

Is there a traditional core to sociology with which most sociologists would agree? Is there a canon of classic writers which all students should read? Insofar as there is one in practice, it is, perhaps, Marx, Weber and Durkheim, with a few additions which are quite variable. These are writers who haveaddressed ques tions of the relationship of individual to society; social inequality and social cohesion; and, in particular, the relationship of class and the dynamics of 
industrialisation. But there is a key limitation, that of the focus on a narrow range of social divisions, social inequalities, especially, that of class at the expense of gender and of ethnicity.

That is not to say that there are not new versions of the old questions. In particular there is a vast agenda in researching and thinking through the issues around the transformation of work, in understanding the future of work, as it is shaped by the new information technologies, by the changed gender composition of the workforce, and the powers of global markets. What will be the nature of jobs - more skilled using educated labour in the knowledge based industries, or decreasingly skilled in the context of globally mobile capital searching for cheap labour?

However, if there is a modern core to sociology it is perhaps rather the trilogy of concepts of class, gender and ethnicity.

Ethnicity has always been an important issue for countries, sometimes defining the group seeking a state in which to institutionalise a nation; sometimes a beleaguered migrant minority; always forming and reforming, despite myths of continuity and asserted essential nature. This will continue to be a vibrant area for sociology, with the reconstruction of nation-states in both East and West Europe; and the increasingly visibility of diaspora and their linkages around the world (Gilroy 1987; YuvalDavis and Anthias 1989; Rex and Tomlinson 1979; Phizacklea and Miles 1980; Phizacklea 1990).

Gender has become a major theme in sociology over the last 25 years and should continue to be a dynamic field in the next century (Barrett 1990; Cockburn 1983; Delphy 1984; Oakley 1974; Phizacklea 1990; Reskin and Roos 1990; Skocpol 1992; Walby 1986, 1990, 1997).
The transformation of gender relations, not only in the UK and most of the industrialised world, as women, in highly uneven ways, enter the public world of employment and more slowly state politics, and yet do not seem to reach full equality will, and should be, a site of much research (Walby 1997). These are major transformations, yet we have only begun to collect the data and develop the concepts needed to understand both the sweep of the changes and their situated specificities. For instance, we do not yet have in many countries, even as we approach the millennium, data on the extent to which men use violence against women. We do not yet really understand the complex implications of the entry of women to the public sphere for women who are differently situated in the macro transformations of the forms of gender regime.

Sociology has been one of the disciplines which as been most welcoming of gender analyses and has benefited from the intellectual vitality as a consequence. However, there are still areas of gender relations where there is much still to do. Most social life is gendered and there are further areas of sociological analyses which should include gender more prominently. In some places the questions and concepts of feminist analysis are finding their way into mainstream sociology, in other places it remains segregated as a specialist topic.

It is sometimes said that 'essentialism' and 'difference' are the key debates in gender studies, in the sociology of gender (Butler 1990; Spellman 1988). That is, the debates on how to conceptualise and analyse the differences between the genders without falling into the trap of essentialising the categories and ending up with a biologically, or even socially, based essentialism. And 
how to analyse the differences between women, so that the category 'woman' is not treated incorrectly as a monolithic whole, with the ensuing problems of this being presumed to be a whole based on the norm of the white Western woman (Carby 1987). These debates are often run together, since the accusation is that 'essentialist' accounts cannot deal adequately with 'difference'.

The debate over the analysis of difference stemmed from the need to avoid the charges of false universalism, of over generalising from the experiences of white Western women. This has led to a lot of self-criticism among writers on gender. While the general critique, of avoiding falsely universalising from the position of one's own ethnicity, is valid, and indeed might be more widely addressed within other branches of sociology, I think the field needs to become more outward looking. For instance, rather than the tendency to focus on local case studies, based on a presumption of the lack of comparability between patterns and experiences of gender relations in different cultures, we might engage in explicit comparative work, to explicitly assess the extent to which there are differences and similarities. Further, while mainstream sociology has started to engage with the rather large research agenda of globalisation we have as yet seen little attempt to gender this debate, despite the very lively debates about women in development (Mies 1986). Thus, gender and globalisation could provide a rich teaching and research agenda, integrating concerns with difference, gender and globalisation.

The related debate of essentialism has also often taken a rather negative tone, with this term being direcred in an extremely critical manner at those who have engaged in generalisations and large-scale theorising (Butler 1990; Yuval-Davis 1997). I think we should not neglect the extent to which critical feminist theory opened up the analysis of the relationship between the social and the biological, the human and nature, especially in analyses of motherhood (Oakley 1974), sexuality (Dworkin 1981), violence (Brownmiller 1976; MacKinnon 1989). These are studies and theories to be build on, again a fruitful area of overlap between feminist and sociological interests, where each has much to contribute to the debate of the other.

I think there is a need to remember to keep the field open and broad, to include all six of my domains/structures employment, household, state, cultural institutions, violence and sexuality and to avoid an agenda which prioritises one at the expense of the other.

Finally, I think we need analyses of change in the structure of gender relations, not only how they are experienced in everyday life, but at the macrolevel analysis of structural changes too. We need large-scale macro-theorising, using large concepts, not only specific case studies of situated gendered practices, using concepts such as patriarchy, or gender regime. We need to develop the work on different forms of gender relations and on the social/natural boundary. We need to understand the impact of the various dimensions of globalisation, on women not only in developing countries, but in the developed world as well.

\section{Beyond the nation-state: The European Union; Globalisation}

The analysis of Europe, and in particular, the EU, is important for sociology, but it is currently a much neglected area. The EU is important for sociolo- 
gists particularly for its distinctive and under-examined social powers. At the moment most of the academic analyses of the EU are performed by other disciplines, especially political science, economics and social policy, leaving the extent and potential of the social powers of the EU under analysed. There is an important agenda for sociology here. The EU is, of course, only one part of Europe and there is a further important agenda for teaching and research on the transformations or transitions currently taking place in Central and Eastern Europe after the collapse of communist regimes. Here, however, only the EU will be addressed.

The unusual nature of the EU is perhaps one of the reasons for a lack of appreciation of its powers. State theory may need to be rewritten in the light of this experience. The EU defies most conventional state theory in at least two major ways. Firstly, it does not have the means of violence, either internally or externally. For instance, according to Weber (1947), states have a monopoly of legitimate violence in a given territory. The EU clearly does not, since it does not have its own armies, militia or police. Attempts to create a military arm (e.g. the European Defence Community in the early 1950s) have failed (Kaptyen 1996).

Secondly, the EU does not build a welfare state using powers of tax and spend, although many contemporary European conceptions of the nation-state include a notion of welfare, in which the community, or society, as represented in the nation, or nation-state 'looks after its own' when they are unable to do so themselves as an essential element (Banting 1995; Habermas 1987; Lange 1992; Ross 1995; Swaan 1994; Titmuss 1974). The EU has exceedingly limited powers to tax and spend (except for the Common Agricultural Policy and Structural Funds to support regional policy), and Member States have a near monopoly on state provided welfare.

Indeed as a consequence, there is a question as to whether the EU is a state or merely an inter-governmental coalition. On the one hand it can be argued that the EU merely follows the bidding of its Member States and thus is not a state in its own right, and on the other that the European Court of Justice and the European Commission act in a manner sufficiently autonomously from the Member States and develop policies which are neither the average, nor the lowest common denominator, but in advance of Member States, so that the designation supra-state is more appropriate.

It is within the debates on globalisation that the interest in the expansion and effectivity of the social powers of the EU are currently centred. The debates on globalisation have raised the question of the capacity of nation-states to act in the face of global markets. Is the EU able to establish a distinctive set of social powers, or are such state-based policies not possible in a globalising economy? Can the EU withstand globalisation?

This question requires an evaluation of the social powers of the EU. This is needed to assess the extent to which globalisation has eroded the power of political entities to develop social policies. It is through the social dimension that the capacity of the EU to effect patterns of social exclusion is potentially deployed. Yet the social dimension is often regarded as weak and relatively ineffectual in the face of European capital (Hantrais 1995; Streeck 1995; Streeck and Schmitter 1992; Bornschier and Ziltener 1998). I think that the social po- 
wers of the EU are underestimated in current social theory for three main reasons:

Firstly, most analysts have a too narrow definition of the social dimension or social policy. This is too often seen solely in terms of welfare programmes based on issues of social need, on policies of tax and spend, which indeed are rather lacking in the EU. But, though important, programmes of social distribution are not the only routes through which a strategy for social justice can be pursued.

Secondly, there has been insufficient regard to forms of social inequality and social exclusion other than class, such as that of gender inequality. Most of the analyses have examined traditional issues of class inequality and the relations between capital and labour. Yet it is within the areas of equal opportunities between women and men, the regulation of pollution and the environment, that some of the most innovative policies have been developed.

Thirdly, sociologists have often underestimated the power of law in the EU. The Treaties are a de facto, if not de jure, constitution of the EU, and thus of its Member States and in consequence have considerable power. The legal mechanisms whereby these Treaties have so much power rest not only on the requirement that governments must revise their domestic legislation to come into line with the Treaties and Directives, but also, and more importantly, the doctrine of 'direct effect' whereby the Treaties and all binding EU instruments, such as Directives, impact directly on all individual citizens of the EU. The doctrine of 'direct effect' means that individuals can appeal directly to the Treaties and Directives of the EU without having to wait for Member States to take intervening domestic legisla- tive reform to comply with the EU (Curtin 1989; Pillinger 1992; Weiler 1997).

An example of the power of the EU is that of the legal floor for equal opportunities policies in employment (Hoskyns 1997). Based on Article 119 of the Treaty of Rome and subsequent Directives, this policy has created many important changes in policies relating to gender relations in employment from ending the marriage bar in Ireland in the mid 1970s to its impact on the wages gap between full-time women and men workers in the UK. Clearly there are significant differences in the impact of such EU policies between Member States, depending on issues such as the nature of the prevailing gender regime and the strength of a feminist lobby, which lead to major differences in the implications of such policies between, for instance, the UK and Denmark. The exact nature of the impact of these regulatory policies is thus a question for further research.

The analysis of the reaction of the EU to perceived globalisation is important for analyses of globalisation. The EU is a polity which has responded aggressively to the perceived threat of globalisation. It is no passive victim in the manner often suggested for nation-states within globalisation theory. During this process the strength of this polity has grown considerably, becoming a fully fledged supra-state, developing new policy capabilities, sometimes at the expense of the sovereignty and capacity for action of its Member States. The EU has demonstrated a response to globalisation in which a polity has been significantly reconfigured and aggrandised. The future development of this process, for instance, with the single European currency, poses further questions for sociological analysis.

However, the EU is not a traditional 
state. It does not have the full range of traditional state powers, such as its own apparatus for organised violence, such as policing and external military engagements. It is a regulatory state.

The legal powers of the EU have been used to take forward projects of social justice by women, as well as consumer protection, environmental protection and matters of health and safety of workers. These have been advanced further than has been possible within their Member States alone. They have been most effective when social and political groups have actively reached over the heads of their national governments to utilise European Union legal instruments. How far can this process go? Is it limited to particular policy domains? What will be the impact of other regulatory dimensions of the EU, such as its fiscal regime?

This analysis and agenda does not require us to underestimate the extent to which the drive by employers to see the completion of the Single European Market is a project of deregulation. Clearly there are important issues in the restructuring of the balance of class forces in the EU project. But a full understanding of the impact of the social dimension will only be reached if we broaden the range of social issues considered central to the analysis of social exclusion so that it includes not only issues related to class and economic marginality, but also ethnicity and age, and, especially, that of gender. Further, the social dimension is relevant to the shaping of the market and the economy as a whole. The EU needs sociological analysis.

\section{Sociology and the Enlightenment Tradition: Sociology and scientific method}

Sociology has undergone much self searching criticism about its relationship to the Enlightenment tradition in which improved knowledge and the advance of science are linked to social progress. I think that sociology should vigorously embrace one part of this, that of scientific methods. In order to argue this I reject the tendency to conflate the notion of the body of scientific knowledge with that of scientific method. Sociology should be proud of and develop its scientific methods. I want to defend scientific methods from the attacks by an unholy alliance of Foucault and feminism.

Foucault (e.g. 1981) and feminism (e.g. Merchant 1980) attack a specific representation of the body of scientific knowledge. They attack it for representing authority, for being a set of beliefs which are passed off as, represented as, or believed to be true as a result of power. This knowledge is itself power, or at least a vehicle for power. The examples which are given significantly overlap: Psychiatry (an early target was critiques of Freud, Millett, Firestone), quasi-medicalised social interventions, institutions to discipline and punish; though there are some variations, in particular, the feminist analysis of ecology and development in the Third World (such as the work of Shiva 1989). There is now a significant position within the sociology of science which sees science as merely yet another social institution, developing this analysis beyond the work of Kuhn on the social dimensions of scientific community and the circumstances of scientific revolutions, to the relativism of Latour.

While I agree that much social scien- 


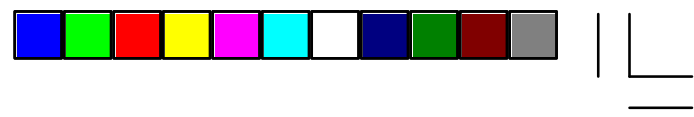

ce asks questions which are disproportionately those which interest dominant social groups, and that it is enmeshed and riddled with power, I think that the relativist alternative of relinquishing of the possibility of establishing procedures for improving knowledge, is to be rejected. We need to distinguish between a critique of the power to have the resources to investigate questions from that of the methods of enquiry. Further, it is not clear that Foucault's absent alternative belief system, religion, which was previously the dominant one, was any the less riddled with power, in fact, perhaps more so.

It might be suggested that the alternative is to engage in critical theory, and following Habermas (1987), argue for the development of the ideal speech situation within which truer knowledge may be created. However, Habermas is more interested in setting up the conditions for adequate public debate, to revitalise the public sphere, than in the methods of science and social science. As such his conditions for establishing the conditions for effective communication do not include some of those necessary for effective science, in particular his work does not have systematic reference to the need to systematically gather empirical data, which is a key feature of scientific method.

Underlying many of the problems with much of this debate on sociology and science is the use of too general and too broad a definition of 'science'. It has become defined as the entire edifice of dominant knowledge in Western societies. I think it is better to conceptually separate this notion from that of scientific method, a much narrower notion relating to scientific procedure. The overall body of knowledge is, obviously, shaped by and implicated in dominant power relations. There are two ways in particular. First, the choice of research topics to be funded, by big business research and development, by government departments, and only marginally by academics whose opportunities are themselves affected by opportunities for jobs and resources. Secondly, the dissemination of findings, especially in the media is a thoroughly social constructionist concern, as for instance Faludi (1992) has shown in the differential publicity to research findings which supported anti-feminist and feminist political conclusions.

The matter of the research methods is a different one. Of course, here it can be argued that some methods are constructed in a masculinist way, in particular modes of abstraction, such as theorising and the use of statistics, rather than focusing on women's own direct accounts (Stanley and Wise 1983), for instance as given by in-depth interviews (Oakley 1981) and ethnographies. Here we see the feminist concern with the patriarchal bias in the methods of the academy, and of the deeply patriarchal nature of existing modes systems of abstract thinking and disciplines, and a belief that knowledge possessed by 'ordinary' women is less 'contaminated' by these patriarchal biases since it is closer to direct experience. This view of knowledge is based implicitly or explicitly upon a notion of feminist standpoint epistemology (Harding 1986).

I profoundly disagree with this. Not that social science is not, still, deeply structured around priorities which diminish women's concerns - it is. But that direct experience is any the less affected by these processes than academic procedures. Everyday experience is also affected by the patriarchal structuring of knowledge, as demonstrated by much feminist cultural studies (Franklin, Lury and Stacey 1991). 


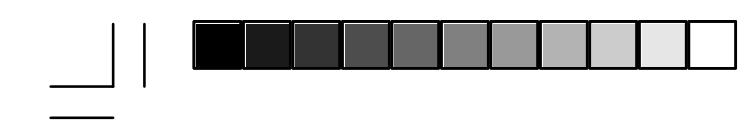

I will take the example of male violence against women. Clearly there is still a problem in the structure of research funding priorities since we do not yet know basic information about the nature and extent of male violence against women even as we approach the millennium, while we know in the finest minutiae issues of men's concerns such as that of the nature and extent of men's paid work. That is, I endorse the feminist critique of the priorities given to the research funding. But I do not think that qualitative accounts provided by some women who have been abused can, even though necessary, be sufficient to provide answers to the question of the overall nature and extent of such violence. Everyday knowledge about violence is also influenced by patriarchally structured cultural institutions. Many women, like most men, have little access to knowledge about violence other than that from popular culture, such as newspapers which carry popular mythology about rape and other violence against women, such as the notion that rape is committed by strangers, rather than men the women know (Soothill and Walby 1991). They are less likely than social scientists to call forced sex 'rape' probably because this word is so stigmatised; and when asked for causes of domestic violence are more likely to report their own immediate action, such as the dinner not being ready, than to turn to theories of male dominance.

In this context there is a clear place and need for scientific method; for rigorous research methods. This is necessary in order to go beyond particularistic knowledge; beyond the myths of newspaper editors and popular knowledge. Such methods are necessary in order to establish knowledge which has a closer consistency with the external world, because it is based on systematic and rigorous empirical enquiry.

Sociology should teach and practice rigorous research methods. This includes the systematic collection, sifting, sorting, analysis of data and its use in building coherent and consistent conceptual and theoretical knowledge. This is a scientific practice which is questioning, based on forever trying to prove others wrong, on the search for constant improvement. Scientific knowledge is constantly changing and being replaced by other knowledge based on further research. I think this more adequately represents scientific method than the accounts such as those of Foucault and Merchant imply. Does this produce truth? I do not think that any scientist thinks they produce other than provisional knowledge, knowledge which is constantly subject to doubt and error, and to improvement. The accusation of hubris directed at scientists is generally misplaced, although there are exceptions, especially when scientists are searching for research funds and representing themselves as the best. Am I saying that Foucault is wrong to allege that the human sciences are utilised to support power, that they constitute a form of power? Yes and no. Yes in that those in power call upon the human sciences as a form of authoritative knowledge and yes in that we do have new modalities of power based on these bodies of knowledge which are articulated through surveillance and in particular through quasi-medicalised discourse of benefit. But this fails to recognise the pluralism and internal critique within the sciences which is a product, indeed necessary part, of their method of procedure, their method of establishing a more authoritative claim to knowledge. The representation of scientists as claiming that they have finally found the 
truth is wrong, since, here more than in other practices for creating knowledge, findings and methods are constantly interrogated. They do not describe 'reality' in a definitive way, but merely at the moment are likely to be less wrong that others in relation to the specific questions that they ask. This scientific knowledge will always be flawed; the theories will always be modified, hopefully constantly and rapidly; that is the nature of the scientific project.

In many of the critiques of science there is a problematic tendency to conflate the overall body of knowledge and scientific method (cf. Merchant 1980). Rather this separation needs to be clearly maintained. Only then can we address separately the issues in each. Understanding of the social nature of scientific communities is no reason for the relativisation of all knowledge claims.

Modern statistics, and, perhaps more importantly, the computers which we operate to use them are immensely more powerful and thus capable of subtlety than before. Large scale data sets are generally under-utilised by sociologists and with them a tendency to cede certain intellectual questions to other disciplines unnecessarily. There is a tendency to cede areas to disciplines such as economics and with it the contribution of sociology to our understanding of important areas of social life, especially that of work. In the UK sociology once made central contributions to the analysis of employment; this is now much less frequent, with such work taking place more frequently in the expanding management schools and in the economics departments, while sociologists move towards analysis of culture. We should reclaim this territory. Our theoretical insights are needed. For instance, economic markets need to be analysed as social institutions rooted in social contexts. The fledgling democracies in the East need sociologists as much as economists to analyse their transformations.

Many sociologists are insufficiently unaware of the new capabilities for data handling. This now includes the handling of qualitative as well as quantitative data. Many of the problems previously identified are very significantly reduced by the power of the new technology. We should reclaim it as a tool, subordinate to the questions of sociology.

\section{Future agendas}

Canon and core: Sociology needs to develop its central concerns beyond those predominant in the work of the nineteenth century sociologists which have become our canon. We need to move beyond the work of Marx, Weber and Durkheim. In particular we need to address the questions posed by gender and ethnicity as well as those of class.

We need a sociology which addresses the questions of our time and which is robust enough not to cede the analysis of the economy to economics, of the polity to political science, and of the cultural to literary studies.

Beyond the nation-state: The time in which it was appropriate for sociology to be bounded by the nation-state in which it is located is, if ever appropriate, now over. The inter-linkages between nation-states, especially with the development of the EU and other regional groupings, and the process of globalisation, mean that the spatial scale relevant to the analysis is now much extended.

This is leading to new forms of institutionalisation of sociology, such as the development of the European Sociological Association, and new forms of the 
communication, such as the Internet. We can expect the increasing internationalisation and speed of exchange of sociological work.

The Enlightenment Tradition: Sociology should embrace and develop a range of scientific research methods. It should be proud of its place in the Enlightenment heritage. The methods selected should, of course, be selected simply on the grounds that they are the best ones to investigate the questions asked.

The analysis of the pressing questions of our day requires sociology, not only the sociological imagination, but sociology as a scientific enquiry.

\section{Bibliography}

Barrett, M. 1980: Women's Oppression Today: Problems in Marxist Feminist Analysis. London: Verso.

Banting, K. 1995: "The welfare state as statecraft:Territorial politics and Canadian social policy", in Leibfried, S. and Pierson, P. (eds.): European Social Policy: Between Fragmentation and Integration. Washington DC: Brookings: 269-300.

Bornschier, V. and Ziltener, P. 1998 (in press): "The revitalization of Western Europe and the politics of the 'social dimension'", in Boje, T., Steenbergen B. van and Walby, S. (eds.) European Societies: Fusion or Fission? London: Routledge.

Brah, A. 1991: "Questions of Difference and International Feminism", in Aaron, J. and Walby, S. (eds.) Out of the Margins: Women's Studies in the Nineties. London: Falmer Press: 168176.

Butler, J. 1990: Gender Trouble: Feminism and the Subversion of Identity. New York: Routledge.

Brownmiller, S. 1976: Against Our Will. London: Penguin.
Carby, H. 1987: “White women listen!”, in Centre for Contemporary Cultural Studies. The Empire Fights Back. London: Hutchinson.

Cecchini, P., Catinat, M. and Jacquemin A. 1988: The European Challenge 1992: The Benefits of a Single Market. Aldershot: Gower.

Cockburn, C. 1983: Brothers: Male Dominance and Technological Change. London: Pluto Press.

Curtin, D. 1989: Irish Employment Equality Law. Dublin: Round Hall Press. Delphy, C. 1984: Close to Home: AMaterialist Analysis of Women's Oppression. London: Hutchinson.

Dworkin, A. 1981: Pornography. London: Women's Press.

Faludi, S. 1992: Backlash: The Undeclared War Against Women. London: Chato and Windus.

Foucault, M. 1981: The History of Sexuality, Volume One: An Introduction. Harmondsworth: Pelican.

Franklin, S., Lury, C. and Stacey, J. (eds.) 1991: Off-Centre: Feminism and Cultural Studies. London: Harper Collins.

Gilman, C. P. 1966 [1898]: Women and Economics: A Study of the Economic Relation Between Men and Women as a Factor in Social Evolution. New York: Harper and Row.

Gilroy, P. 1987: There Ain't No Black in the Union Jack: The Cultural Politics of Race and Nation. London: Hutchinson.

Habermas, J. 1987 [1981]: The Theory of Communicative Action Volume 2: Lifeworld and System: A Critique of Functionalist Reason. Cambridge: Polity.

Hanmer, J. and Saunders, S. 1984: Well Founded Fear: A Community Study of Violence Toward Women. London: Hutchinson.

Hantrais, L. 1995: Social Policy in the European Union. Basingstoke: Macmillan. 
Harding, S. 1986: The Science Question in Feminism. Ithaca: Cornell University Press.

Held, D. 1995: Democracy and the Global Order: From the Modern State to Cosmopolitan Governance. Cambridge: Polity Press.

Hirst, P. and Thompson, G. 1996: Globalization in Question: The International Economy and the Possibilities of Governance. Cambridge: Polity Press.

Hoskyns, C. 1996: Integrating Gender: Women, Law and Politics in the European Union. London: Verso.

Kapteyn, P. 1996: The Stateless Market: The European Dilemma of Integration and Civilization. London: Routledge.

Lange, P. 1992: "The politics of the social dimension", in Sbragia, M.A. (ed.) Euro-Politics: Institutions and Policymaking in the "New" European Community. Washington DC: Brookings: 225-256.

Leibfried, S. and Pierson, P. (eds.) 1995: European Social Policy: Between Fragmentation and Integration. Washington DC: Brookings.

Mackinnon, C. 1989: Toward a Feminist Theory of the State. Cambridge, Mass.: Harvard University Press.

Merchant, C. 1980: The Death of Nature: Women, Ecology and the Scientific Revolution. New York: Harper and Row.

Mies, M. 1986: Patriarchy and Accumulation on a World Scale: Women in the International Division of Labour. London: Zed Books.

Nicholson, L. (ed.) 1990: Feminism/Postmodernism. New York: Routledge.

Oakley, A. 1974: The Sociology of Housework. Oxford: Martin Robertson.

Oakley, A. 1981: "Interviewing women: a contradiction in terms", in Roberts, H. (ed.) Doing Feminist Research. London: Routledge.

Phizacklea, A. 1990: Unpacking the Fas- hion Industry. London: Routledge. Phizacklea, A. and Miles, R. 1980: Labour and Racism. London: Routledge.

Pillinger, J. 1992: Feminising the Market: Women's Pay and Employment in the European Community. Basingstoke: Macmillan.

Reskin, B. and Roos, P. 1990: Job Queues, Gender Queues: Explaining Women's Inroads into Male Occupations. Philadelphia: Temple University Press.

Rex, J. and Tomlinson, S. 1979: Colonial Immigrants in a British City: A Class Analysis. London: Routledge.

Ross, G. 1995: "Assessing the Delors era and social policy", in Leibfried, S. and Pierson, P. (eds.) European Social Policy: Between Fragmentation and Integration. Washington DC: Brookings: 357-388.

Swaan, A. de 1994: "Perspectives for transnational social policy in Europe: Social transfers from West to East", in Swaan, A. de (ed.) Social Policy Beyond Borders: The Social Question in International Perspective. Amsterdam University Press: 101-115.

Segal, L. 1987: Is the Future Female? Troubled Thoughts on Contemporary Feminism. London: Virago.

Shiva, V. 1989: Staying Alive: Women, Ecology and Development. London: Zed Press.

Soothill, K. and Walby, S. 1991: Sex Crime in the News. London: Routledge.

Spellman, E. 1988: Inessential Woman: Problems of Exclusion in Feminist Thought. Boston: Beacon Press.

Stanley, L. and Wise, S. 1983: Breaking Out: Feminist Consciousness and Feminist Research. London: Routledge.

Streeck, W. 1995: “From market making to state building? Reflections on the political economy of European social policy", in Leibfried, S. and Pierson, P. (eds.): European Social Policy: Between Fragmentation and Integra- 
tion. Washington DC: Brookings: 389-431.

Streeck, W. and Schmitter, P.C. 1992:

"From national corporatism to transnational pluralism: Organised interests in the single European Market", in Streeck, W. Social Institutions and Economic Performance: Studies of Industrial Relations in Advanced Economies. London: Sage.

Tinker, I. (ed.) 1990: Persistent Inequalities: Women and World Development. New York: Oxford University Press.

Therborn, G. 1998 (in press): "Europe", in Boje, T., Steenbergen, B. van and Walby, S. (eds.) European Societies: Fusion or Fission? London: Routledge.

Titmuss, R. M. 1974: Social Policy: An Introduction. London: Allen and Unwin. Touraine, A. 1998 (in press): “Europe be- tween integration and fragmentation", in Boje, T., Steenbergen, B. van and Walby, S. (eds.) European Societies: Fusion or Fission? London: Routledge.

Walby, S. 1986: Patriarchy at Work. Cambridge: Polity.

Walby, S. 1990: Theorizing Patriarchy. Oxford: Blackwell.

Walby, S. 1997: Gender Transformations. London: Routledge.

Weber, M. 1947: The Theory of Economic and Social Organization. New York: Free Press.

Weiler, J.H.H. 1997: "The reformation of European Constitutionalism". Journal of Common Market Studies, 35 (1): 97-129.

Yuval-Davis, N. and Anthias, F. (eds.) 1989: Woman-Nation-State. London: Macmillan. 